Historic, Archive Document

Do not assume content reflects current scientific knowledge, policies, or practices. 



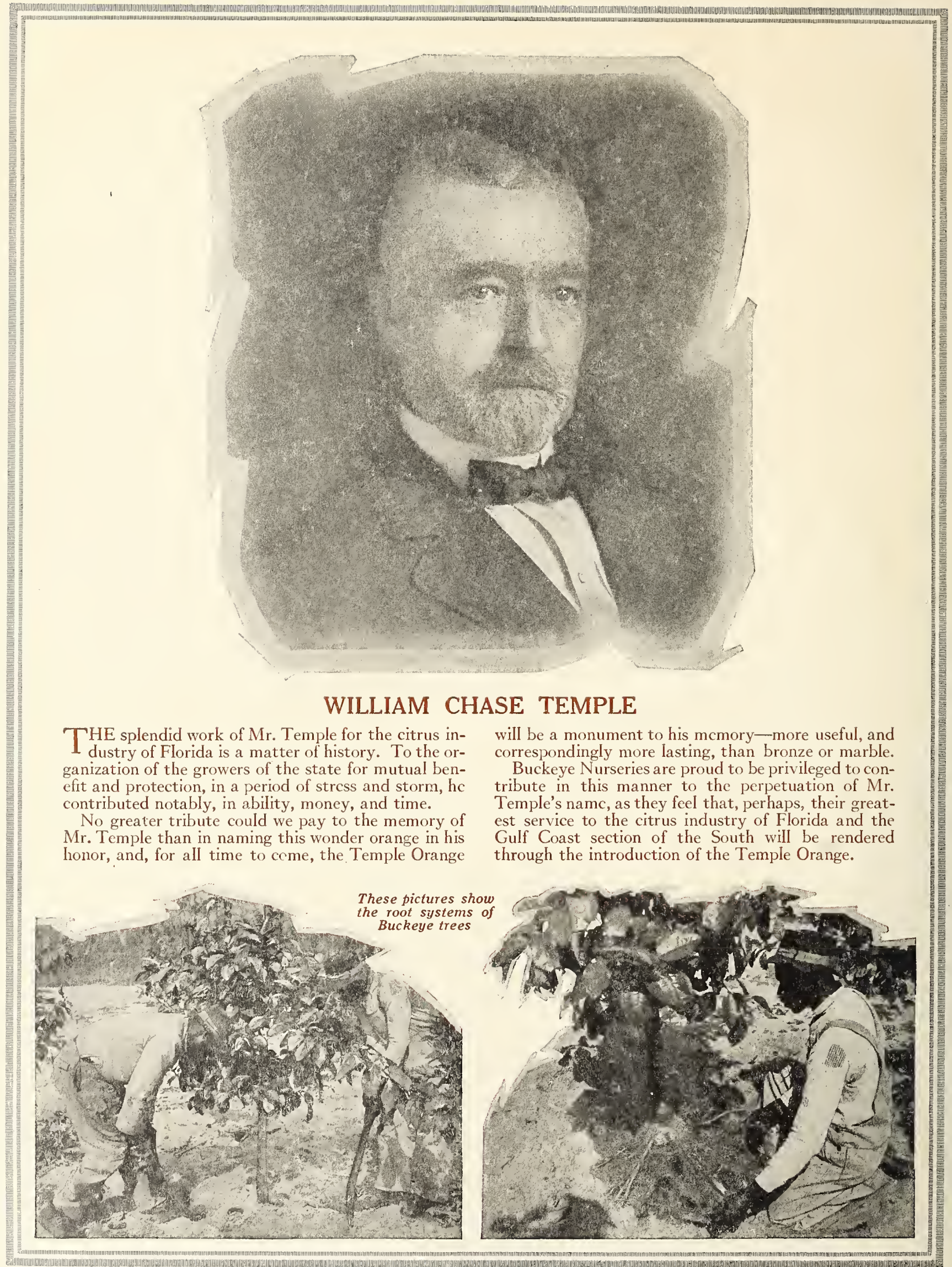

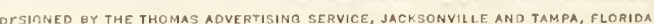

(C) $\operatorname{ClA5} 33250$ 
LARGEST EXCLUSIVELY CITRUS NURSERIES IN THE WORLD

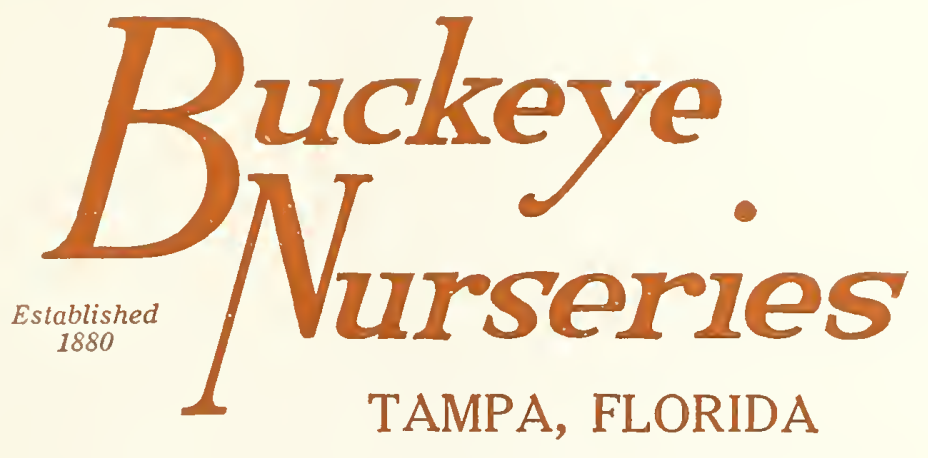

THE PARENT TREE OF THE TEMPLE ORANGE

THE photograph of the parent Temple tree from which has been reproduced this engraving was made 1 during the rig session of the Florida State Horticultural Society, beld in Orlando.

Among the prominent growers shown in the picture, who evidenced their interest in the Temple orange by. making a trip to the grove in which the parent tree stands, may be mentioned the following:

Dr. J. H. Ross, C. E. Stewart, Jr., L. B. Skinner, S. F. Poole, J. W. Sample, R. F. Walker, Louis Geiger,

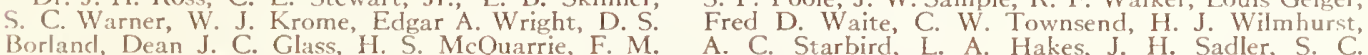
O’Byrne, W. F. Miller, W. S. Hart, Arthur H. Brown, Inman, E. H. Buffum.

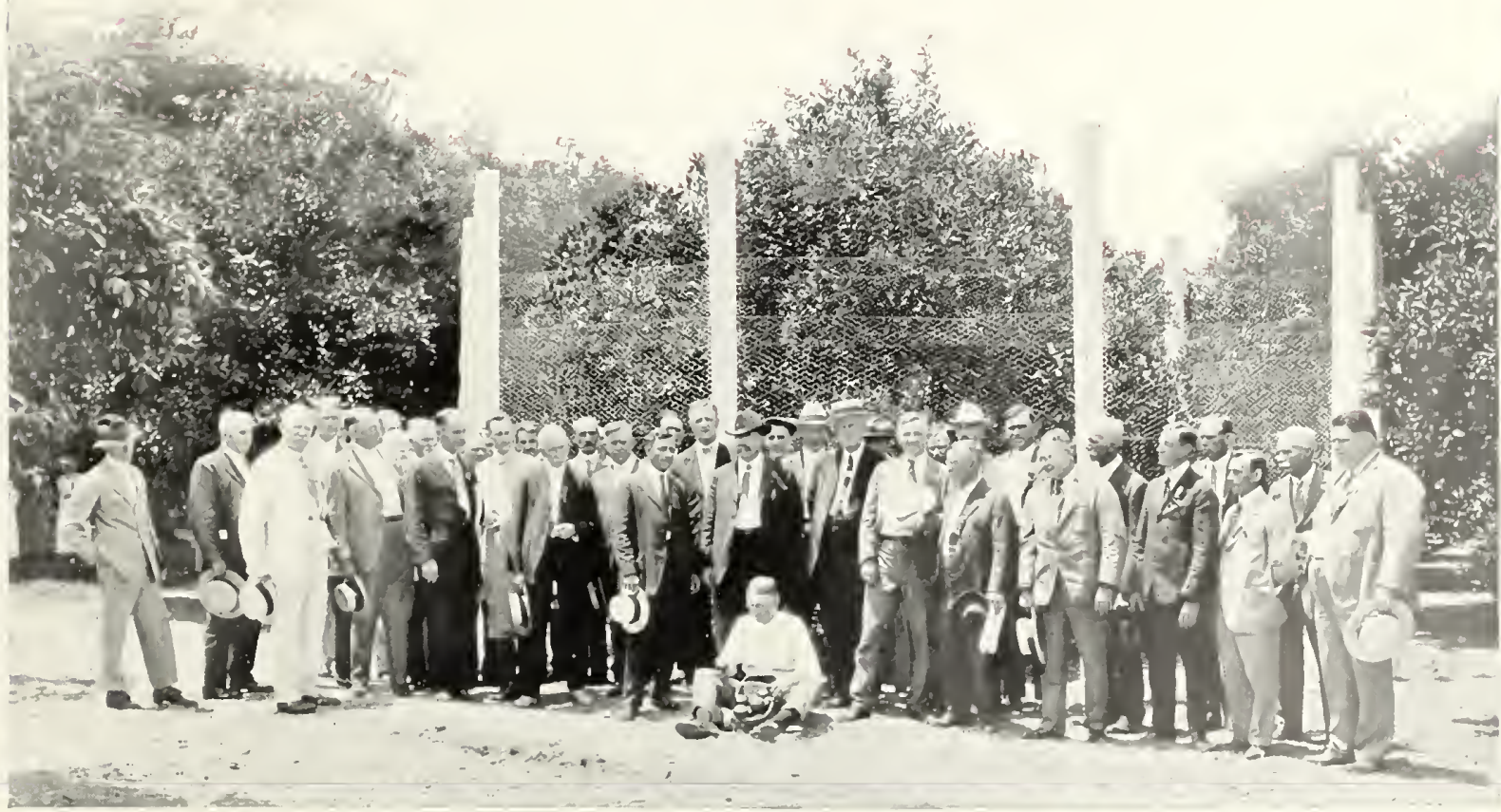


BUCKEYE NURSERIES 

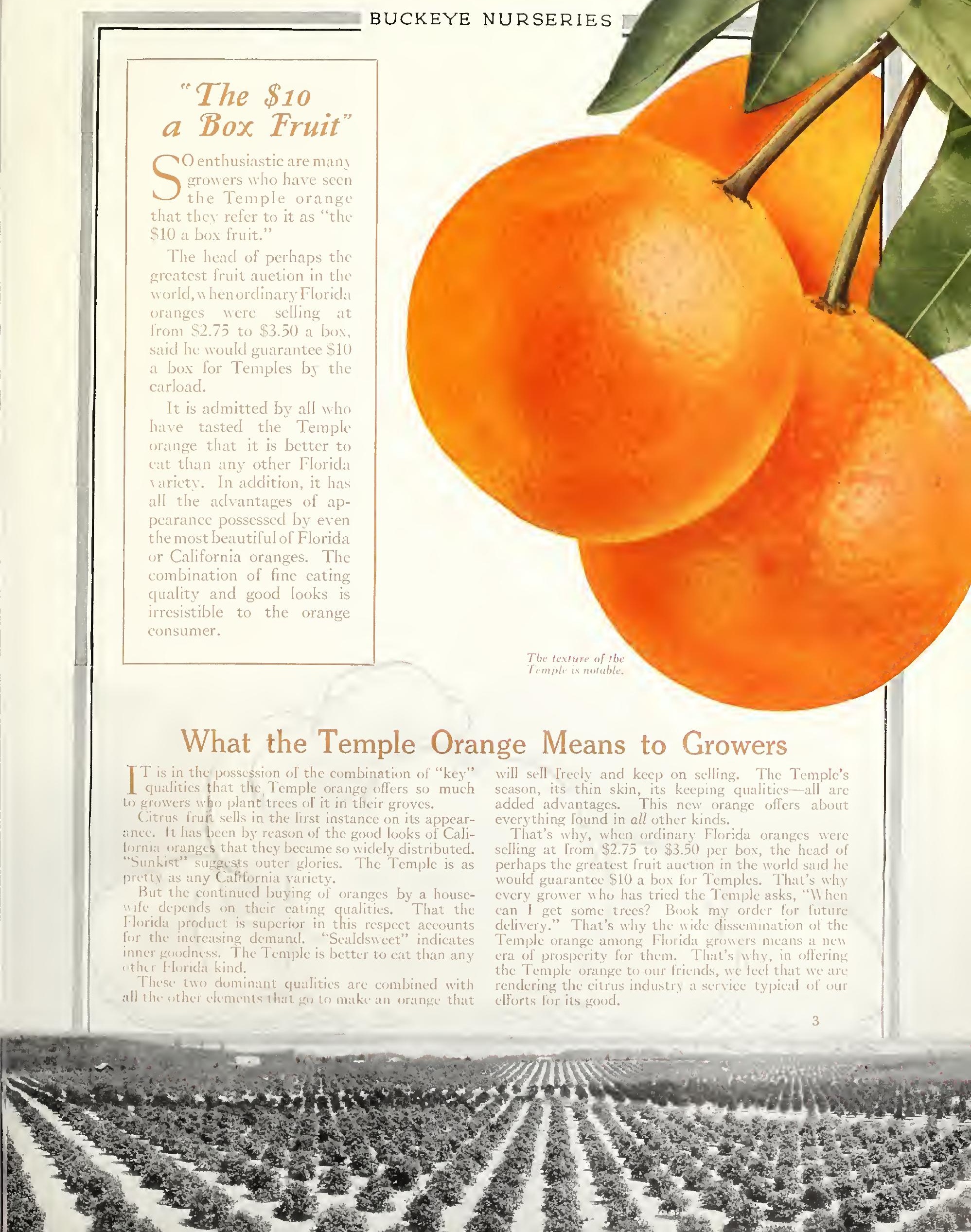


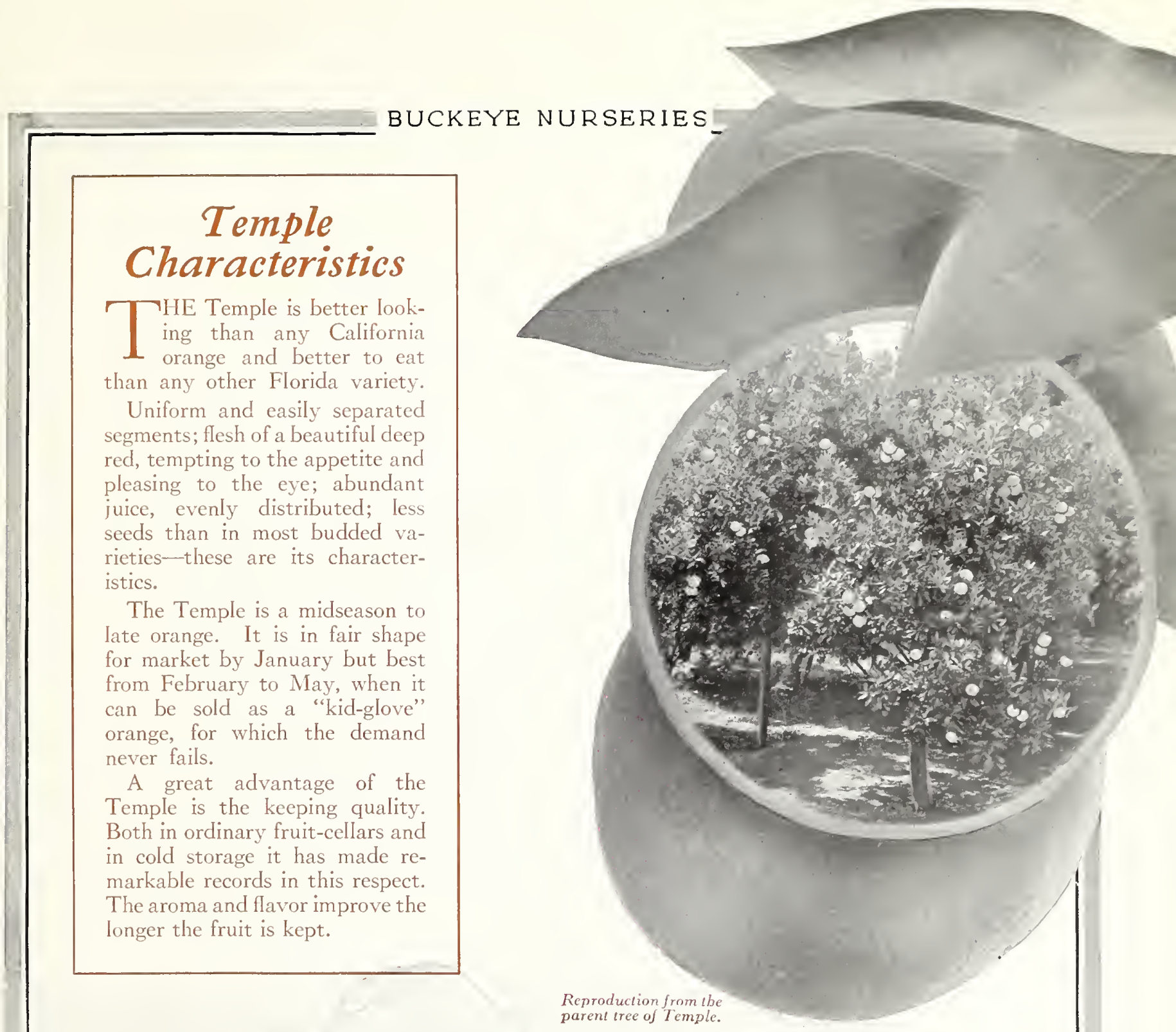

\section{Interest of Growers in the Temple}

WITH very little advertising, the Temple has become one of the best-known oranges in Florida. As one grower has learned of it, he has told othors, and they, in turn, have passed on the word of this remarkable new varicty, until the news of its merits has penctrated every section of the citrus belt. As the parent tree is located but a few miles from Orlando, it was but natural that when the Statc Horticultural Society met there its members in large number should take advantage of the opportunity to see this trce. A picture showing some of the promincnt growers who were in the party which made the trip to the Tcmple tree is given on pagc one. In an cditorial referring to the meeting, the Tampa Tribune said:

"The session of the Florida State Horticultural
Society in Orlando last week presented an interesting program to a very large attendancc. In addition to the discussions there ivere many subjeets of vital interest to growers. The Orlando meeting included a pilgrimage by automobile to the grove of $\mathrm{L}$. A. Hakcs, at Winter Park, where visitors were shown the original Temple orange tree, now about twenty years old. "The Templc orangc today is the sensation of the Florida citrus industry, it being declared by many that it promises to bc to Florida what the navel orange has been to California. D. C. Gillett showed the visitors reproductions, grown from budwood taken from the Templc trcc, which carricd all the dominant Tcmple characteristics, including the remarkable Temple color, texturc, and aroma. The ncw orange is named in honor of the latc William Chasc Temple."

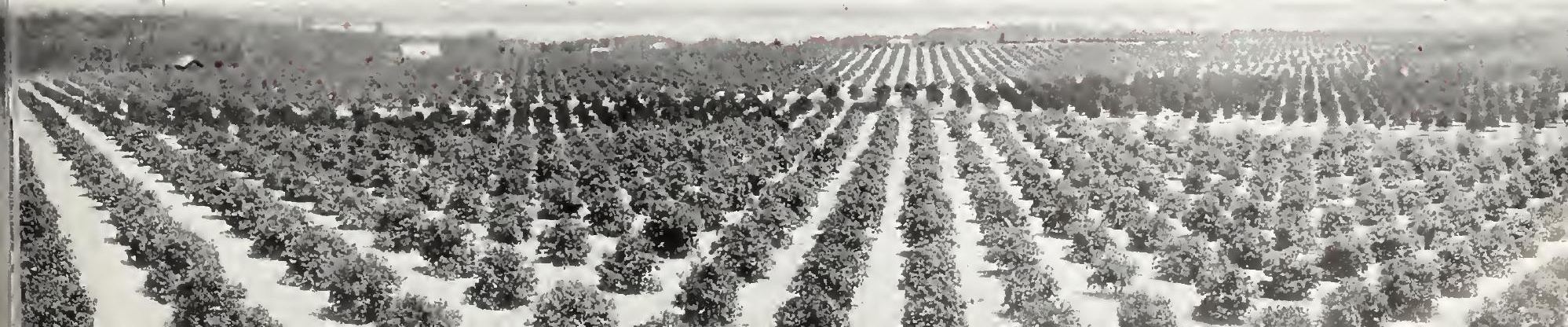




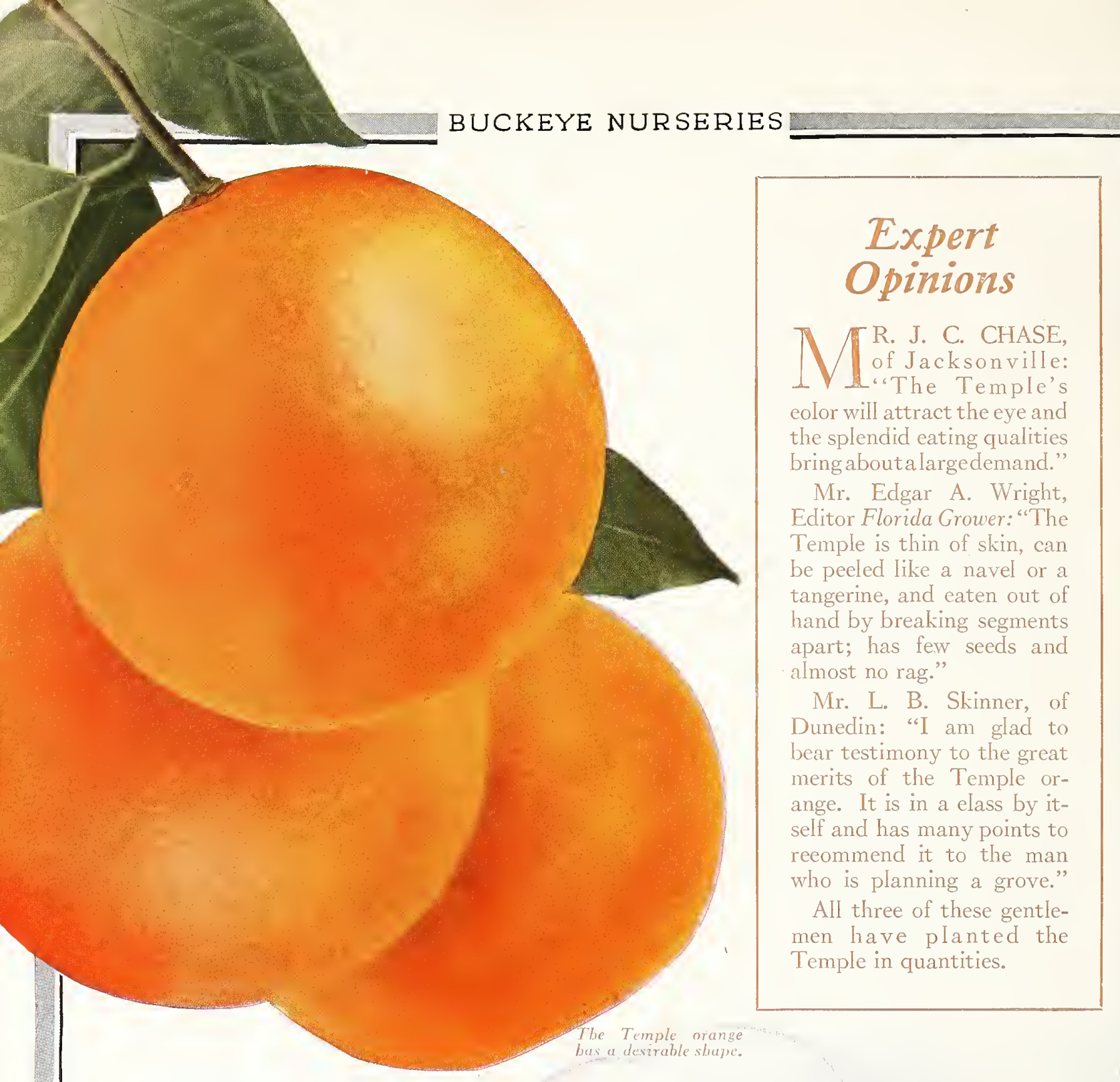

\section{Sales of Temple Trees Confined to the South}

A UNIQUE feature of the sale of trees of the A Temple orange by Buckeye Nurseries is that it is confined to the South.

The decision to make this territorial restriction is an expression of the appreciation of Buckeye Nurseries for the splendid support they have received from the citrus industry of the Gulf Coast.

As a practical matter of dollars and cents to the growers of Florida and the South, it is difficult to overestimate the value of this plan of exclusively selling Temple trees, so much does it mean to the citrus growers of this section.

California long has had two advantages ovcr the eastern citrus belt, in the beauty of her. Valencia oranges and the fact that her navels could not be com-. peted with by fruit of that variety grown elsewhere.
The new Temple orange is just as attractive to the eye as any strain, and its eating qualities are superior to those of any other variety, no matter where grown. The fact that for many years at least fruit of the Temple will be marketed only from a restricted area, places the growers of the Temple in a favored position.

No longer than the coming into bearing of the Temple trees reeently planted and soon to be planted, will consumers buy competitive oranges because of their better appearance when compared with fruit from Florida and other Gulf Coast states. And as these Temple trees produce the oranges that their owners will market so profitably, because of beauty of outward appearance and inward deliciousness, the - Temple will revolutionize the orange industry.

6

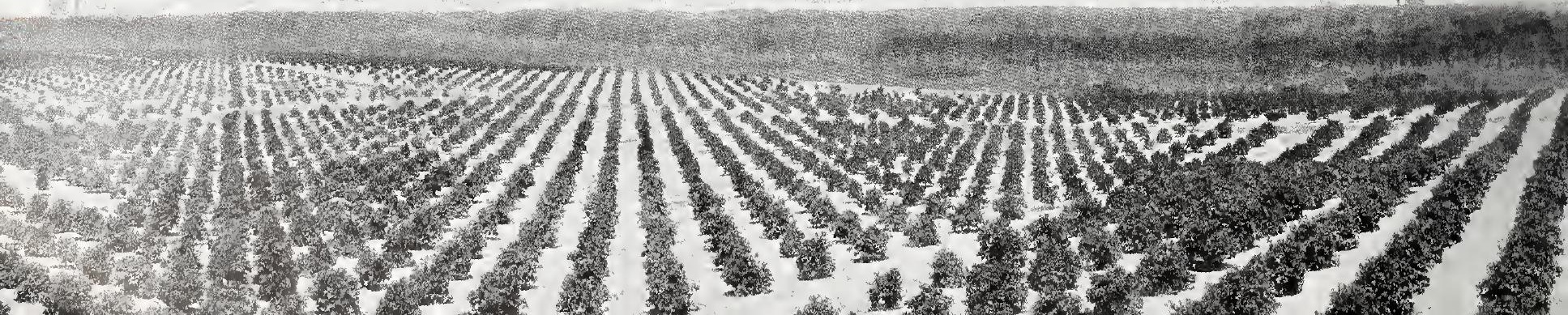



BUCKEYE NURSERIES, Tampa, Florida

Gentlemen: For my account, please enter order for Temple Orange Trees,

on Stock. (Write R. L. for Rough Lemon, S. O. for Sour Orange, U. Y. D. for Use Your Discretion.)

Find enclosed, $\$$ Ship by

(Write here "Freight," "Express," or "Use Your Discretion.")

When

(Write here date on which shipment is to be made.)

This space for full shipping directions, without reference to
Post Office address of purchaser.

Via
淁- This space for name and Post Office address of purchaser, without reference to destination of shipment. Ladies, please give title, Miss or Mrs.

Name

St. and No.or P. O. Box

赵

Post Office

State

To protect myself and other purchasers of Temple Orange Trees against the competition of inferior fruit sold under the same name, and to protect you in the right to exclusively propagate and distribute this orange, and in consideration of the fact that you are to supply me the trees ordered above at the special price each, I agree not to sell or give away, or to permit anyone else to take any scions, buds or cuttings from these trees, or from their progeny, for a period of twenty-five years.

I further agree not to sell or give any of these trees away, and in case of disposition of property on which the trees are planted, I obligate myself to make this agreement a condition of the transfer.

(Signed)

Explanation of the Order Sheet and Protection Agreement Printed Above

You will notc in the order blank herewith a clause binding you not to dispose of any budwood of the trees of the Temple orange or of the trecs themselves.

This agreement is both for your protcction and for ours. We regard it of just as much importance, if not more, from your standpoint as from ours and believe you will agree with us.

If the propagation and distribution of trees of this new orange are not confined to a single dependable and responsible channel, all sorts and kinds of strains of Temple oranges will be offered within a few seasons.

The fruit of some of these strains, if indeed not that of all of them, except the original from Buckeye Nurseries, will be inferior and when this poorer stuff is marketed under the Temple name it will have a tendency to lower the prices offered for true Temple oranges.

By the restrictions we are placing on the sale of Temple budwood and trees, we are endeavoring to, just as far as possible, protect our customers against this condition. You know that the fruit of the true Parson Brown or Pineapple orange, for instance, does not sell as well as it would if there were none of the false strains in the market.

This agrcement providing against the sale of budwood also is for our protection against unfair competition. We not only paid a largc sum of money for the original Temple tree but we have been at great expense in thoroughly testing out this fruit and reproducing it and in propagating trecs under conditions which assure us that they are healthy, true to name and in every way first class. It is but common fairness and simple justice that all sclling rights in the Temple orange should be our property. 


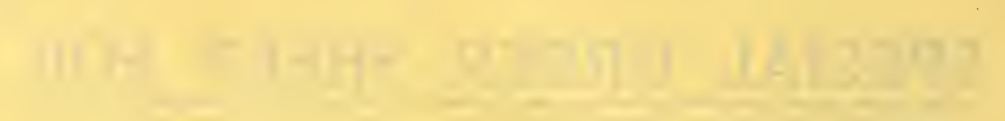




\section{Buckeye Nurseries \\ 1015 Citizens Bank Building \\ TAMPA, FLORIDA}

\section{Price List}

Effective May 15, 1919

All Varieties of Grapefruit, Oranges, (except Temple), Lemons, Limes and Tangelos.

\begin{tabular}{|c|c|c|c|}
\hline Grade & 10 & 100 & 1,000 \\
\hline 2 to 3 feet. . .\$.60 & $\$ 5.50$ & $\$ 50.00$ & $\$ 450.00$ \\
\hline 3 to 4 feet.... .80 & 7.00 & 65.00 & 600.00 \\
\hline to 5 feet.... 1.00 & 9.00 & 85.00 & 800.00 \\
\hline to 7 feet. & 11.50 & 110.00 & $1,000.00$ \\
\hline years. & 16.00 & 140.00 & $1,250.00$ \\
\hline ENPLE & 27.50 & 225.00 & $2,000.00$ \\
\hline
\end{tabular}

NOTE-The price of the Ternple is for the best trees unsold, when order is received. Trees range in size from two years to 3-4 $\mathrm{ft}$. grade.

\section{KUMQUATS}

\begin{tabular}{|c|c|c|}
\hline Each & 10 & 100 \\
\hline$\ldots . \$ \quad 85$ & $\$ 7.00$ & $\$ 65.00$ \\
\hline . 1.10 & 10.00 & 90.00 \\
\hline
\end{tabular}

EXPLANATION-The price for single trees in the first column applies on all orders for 4 trees or less; the ten rate applies on orders of from 5 to 49 trees; the hundred rate on 50 to 499 trees, and the thousand rate on 500 or more, regardless of the varieties ordered and the number of each.

\section{CAIIPER}

The average caliper of Grapefruit trees and the standard varieties of Orange is about as follows:

2- to 3-foot grade sold by height alone.

3 - to 4 -foot grade will caliper $1 / 2$ to $5 / 8$ inch.

4- to 5-foot grade will caliper $5 / 8$ to $3 / 4$ inch.

5 - to 7 -foot grade will caliper $3 / 4$ to 1 inch.

2 year grade will caliper 1 to $1 \frac{1}{4}$ inches.

Grade, given in feet, refers to height as trees stand in nursery. They are cut back materially before shipment, unless customer specifically instructs otherwise.

We reserve the right to sell either by caliper or height. The Temple, King and Tangerine Oranges, as well as Limes, being of much more slender growtl, may not caliper so large as the above. Kumquats are of dwarf growth and are sold by age only.

\section{ADDITIONAL INFORMATION ON SIZES AND GRADES OF TREES}

The different grades of all trees are of the following ages of root and bud:

2 to 3 foot carries 10 -month bud, 30 -month root.

3 to 4 foot carries 12 -nonth bud, 36-month root.

5 to 7 foot carries 15 -month bud, 51-month root.

2-years carries 24-montl bud, 60-1110uth root.

4 to 5 foot carries 12 -month bud, 48 -month root.

ILLUSTRATION-500 or more trees in the 5 to 7 -foot size are worth $\$ 1.00$ each packed f. $o$. b. our Nursery at Temple, near Winter Haven. $\Lambda 5$ to 7 -foot tree will caliper $3 / 4$ to 1 inch, and carries a 15 -month bud on a 51 -month root.

\section{NUMBER OF TRE ES TO THE ACRE}

Dist. Apart feet

19 by 19 .

20 by 20

25 by 25

30 by 30

35 by 35

40 by 40

25 bs 30
No. Trees

120 108

69

48

35

27

60
For commercial planting, we generally recommend that trees be planted in squares 25 by 25 , requiring 69 to the acre.

Copies of Testimonial Letter's from buyers of Buckeye Trees who have planted on land near yours will be sent on request. 


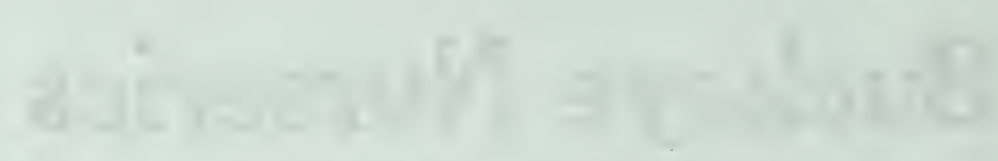




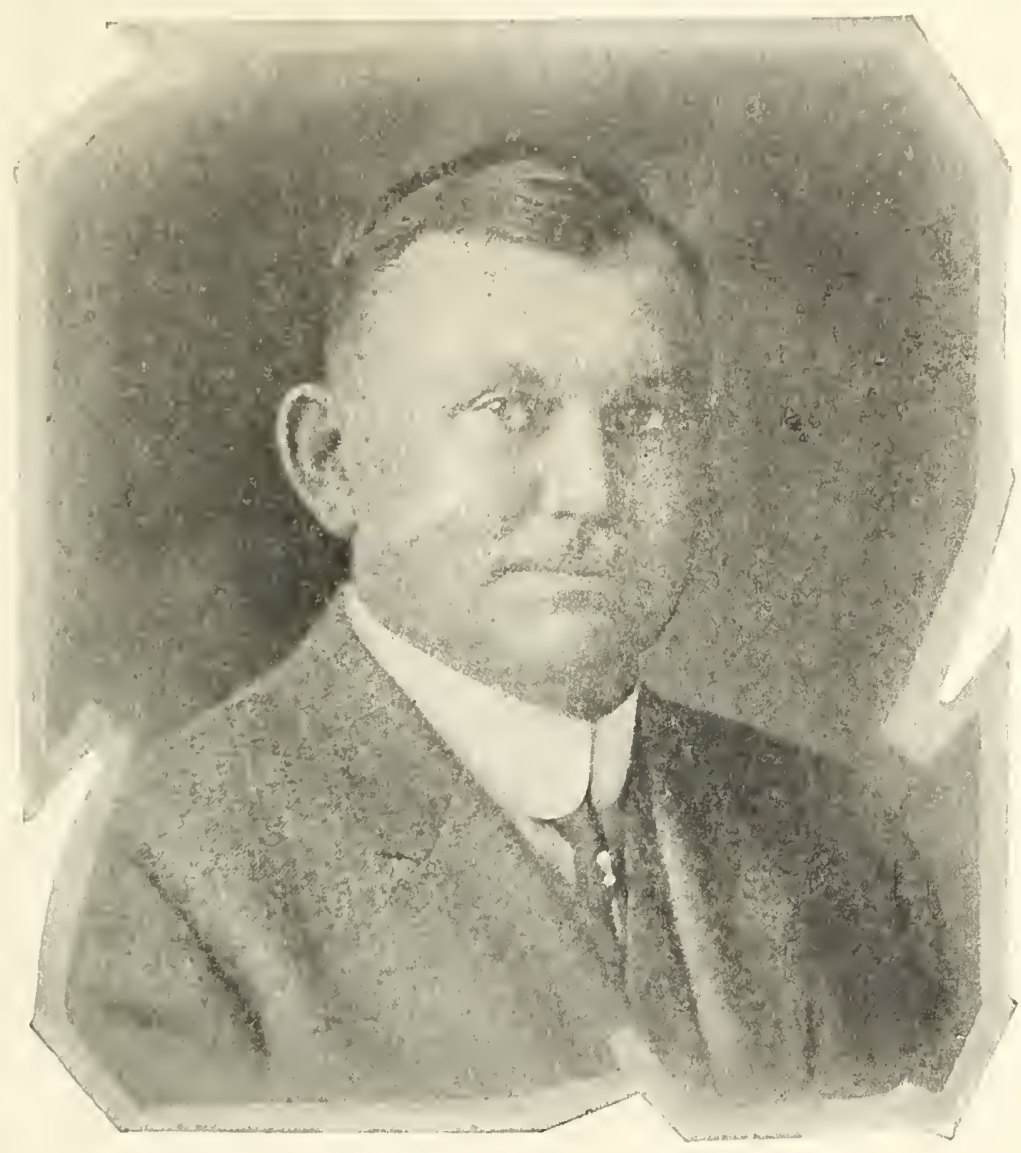

MYRON E. GILLETT

'THE senior member of the firm of M. E. Gillett \& Son, 1 proprietors of Buekeye Nurseries, has been a familiar figure to the eitrus growers of Florida for forty years. Beeoming less active physieally as the years pass, Mr. Gillett's ideas and ideals, more than ever, are dominant in the great business he founded and developed.

Buekeye Nurseries made their reputation on quality of product and on service to purehasers. Myron Gillett is just as insistent that these guiding principles of the enterprise shall be observed today as he was when the business was in its infaney. The younger men who are taking his plaee on the firing-line of production and sales are pleased to have the privilege of following faithfully the example and the preepts of their employer and friend. It is unnecessary to state that this tribute to Mr. Gillett is without his knowledge or consent.
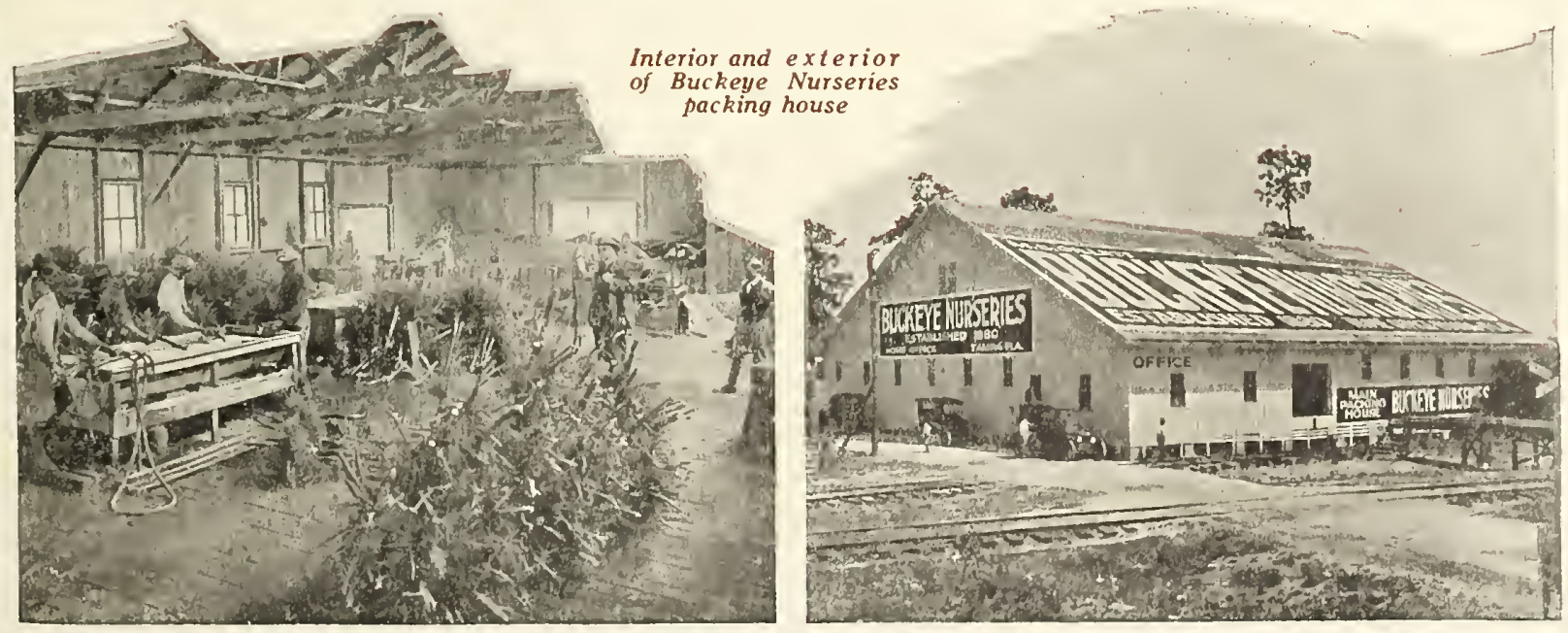

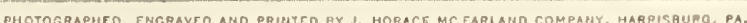


